Agr. Biol. Chem., 39 (6), 1201 1206, 1975

\title{
Suppression of Spoilage Rates of Bombay Duck (Harpodon nehereus) Homogenates by Gamma Radiation
}

\author{
M. D. Alur, N. F. Lewis, S. S. Mavinkurve and U. S. Kumta \\ Bhabha Atomic Research Centre, Biochemistry and Food Technology Division, \\ Trombay, Bombay 400085 , India \\ Received October 30, 1974
}

\begin{abstract}
The spoilage rates of unirradiated and irradiated $(0.1 \mathrm{Mrad})$ Bombay duck (Harpodon nehereus) homogenates stored at $0^{\circ} \mathrm{C}, 10^{\circ} \mathrm{C}$ and $30^{\circ} \mathrm{C}$ in terms of organoleptic score (OS) total bacterial count (TBC), trimethylamine content (TMA), and total volatile basic nitrogen (TVBN) followed a linear response with increase in temperature. Unirradiated Bombay duck stored at $0^{\circ} \mathrm{C}$ were found to spoil faster than those irradiated at $0.1 \mathrm{Mrad}$; the spoilage rates derived for TBC, TMA, TVBN and OS were $0.42,0.67,1.93$ and -0.86 respectively for unirradiated samples as compared with corresponding values of $0.31,0.55,1.19$ and -0.19 for the irradiated samples. The spoilage rates of unirradiated Bombay duck stored at $10^{\circ} \mathrm{C}$ and $30^{\circ} \mathrm{C}$ measured as a function of OS, TMA and TVBN were consistently higher than their irradiated $(0.1 \mathrm{Mrad})$ counterparts. In the case of irradiated samples, TBC was not a satisfactory index of spoilage.
\end{abstract}

The two important parameters in the radurization process are the radiation dose administered $^{(\sim 3)}$ and the temperature during storage of irradiated sea-foods. ${ }^{4}$ The main disadvantages of using high radurization doses are (i) spoilage microflora are inactivated ${ }^{11}$ thereby increasing the probability that such processed food could harbour toxigenic Clostridium botulinum since there would be less inhibitory influence on their growth, and (ii) loss of organoleptic attributes like color, flavor and texture. Current research is therefore aimed at using lower doses (0.1 Mrad $\sim 0.2 \mathrm{Mrad}$ ) for limited extension in shelf-life of sea-foods, which treatment will not significantly alter the spoilage pattern from that of unirradiated samples.

Irradiation thus offers tremendous scope for transportation of radurized fish from the processing plant to distant areas, provided the temperature during transport is maintained between $0^{\circ} \mathrm{C} \sim 3^{\circ} \mathrm{C}$ for control of $\mathrm{Cl}$. botulinum. ${ }^{2,5}$ In view of the stipulated temperature requirement, it is important to define a suitable scale in terms of freshness indices to determine fluctuations in temperature of the sea-foods which may occur during transporta- tion.

Spencer and Baines ${ }^{6)}$ have formulated a mathematical correlation between spoilage rates and storage temperature of fish. The validity of this formula for irradiated Bombay duck (Harpodon nehereus) has been reported. ${ }^{7}$

This paper provides detailed data for the recommendation of the formula of Spencer and Baines ${ }^{6)}$ to be applicable to low dose irradiated sea-foods.

\section{MATERIALS AND METHODS}

Fresh Bombay duck obtained from the local market were washed, eviscerated and filleted. $10 \mathrm{~g}$ samples were homogenised for $2 \mathrm{~min}$ with $90 \mathrm{ml}$ sterile normal saline in omni-mixer cups. The fish homogenate was asceptically transferred in $10 \mathrm{ml}$ portions into sterile test tubes, which were immediately exposed to gamma radiation at a dose level of $0.1 \mathrm{Mrad}$.

Irradiation. Irradiation was carried out in a $\mathrm{Co}^{60}$ gamma cell 220 (Atomic Energy Canada Ltd.) at a dose rate of $11,100 \mathrm{rads} / \mathrm{min}$. Unirradiated samples served as controls. For calculation of spoilage rates both the controls and irradiated samples were held at 3 different storage temperatures viz. $0^{\circ}, 10^{\circ}$ and $30^{\circ} \mathrm{C}$. Representative samples were analysed for organoleptic, bacteriological and biochemical tests, at pre-determined intervals. 
Organoleptic evaluation. Sensory scoring was done according to the Miyauchi et al., ${ }^{81}$ reference scale which is based upon changes in odors.

Chemical analysis. TMA and TVBN were determined in TCA extracts according to the methods adopted previously for Bombay duck. ${ }^{9 !}$

Bacteriological examination. The total aerobic bacterial count (TBC) was assessed by the pour plate method using Tryptone-Glucose-Yeast-Extract agar (TGY agar). Appropriate dilutions were plated in triplicate. Plates were incubated for $48 \mathrm{hr}$ at $27 \sim$ $28^{\circ} \mathrm{C}$.

Spoilage units. Spoilage rates of the samples in terms of TBC, TVBN and organoleptic ratings were determined by the least square method. TMA content in fish muscle was converted into a TMA-index, defined as $10 \times \log (1+$ TMA content $)$, for determining the spoilage units. ' $\mathrm{C}$ ', the linear temperature response of unirradiated and irradiated homogenates was derived from the spoilage rates using Spencer and Baines' formula: $\mathrm{C}=(\mathrm{U}-\mathrm{V}) /(\mathrm{V} \times \theta)$, where $\mathrm{C}=$ linear temperature response; $\mathrm{U}=$ spoilage rate at $\theta^{\circ} \mathrm{C} ; \mathrm{V}=$ spoilage rate at $0^{\circ} \mathrm{C}$ and $\theta=$ specific storage temperature.

\section{RESULTS AND DISCUSSION}

Storage properties of unirradiated homogenate

Unirradiated samples incubated at $30^{\circ} \mathrm{C}$ showed precipitous decline in organoleptic acceptability. From the nature and intensity of putrid odors, a score of 5 was assigned to samples incubating for $7 \sim 8 \mathrm{hr}$ (Fig. 1). However, samples similarly stored at $10^{\circ}$ and $0^{\circ} \mathrm{C}$ showed signs of spoilage only after 5 and 7 days of storage respectively (Figs. 2 and 3). The storage temperature also influenced the nature of spoilage odors of the homogenates at the terminal spoilage. Thus, recognisable putrid odors were encountered at the terminal spoilage in the homogenates stored either at $10^{\circ}$ or $30^{\circ} \mathrm{C}$, as compared with samples stored at $0^{\circ} \mathrm{C}$ which developed unacceptable sweetish odors.

An inverse relationship is observed between rise in TBC, TMA, TVBN and fall in organoleptic scores during storage of the unirradiated homogenates. Total bacterial counts of $10^{8} \sim 10^{9} / \mathrm{g}$ accompanied by large TVBN values of $100 \mathrm{mg} \mathrm{N} \%$ and $20 \mathrm{mg} \mathrm{N} \%$ at $30^{\circ} \mathrm{C}$ and $10^{\circ} \mathrm{C}$ respectively are concurrent

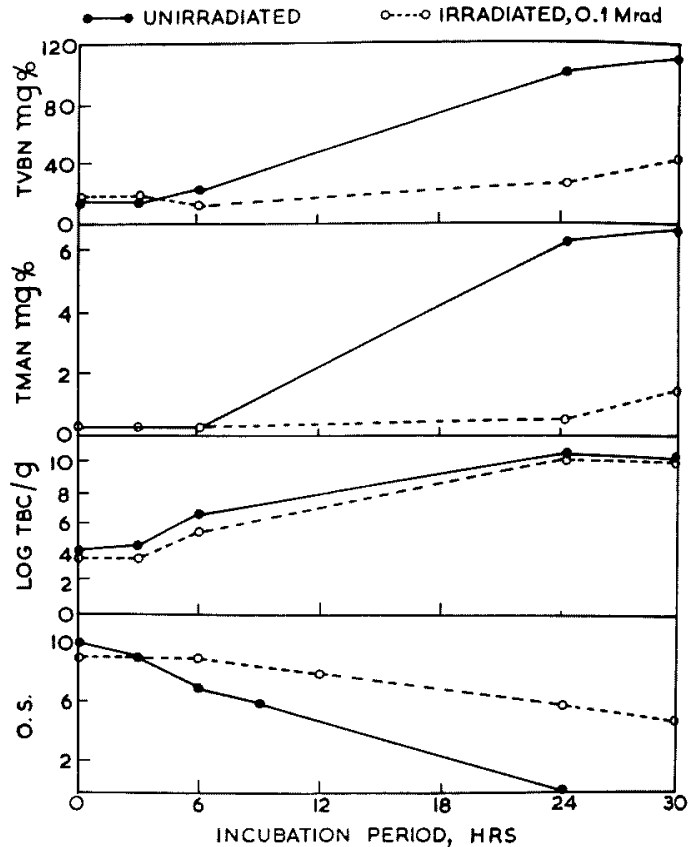

FIG. 1. Status of Freshness Indices in Unirradiated and Irradiated Bombay Duck Homogenates (incubation temperature $30^{\circ} \mathrm{C}$ ).

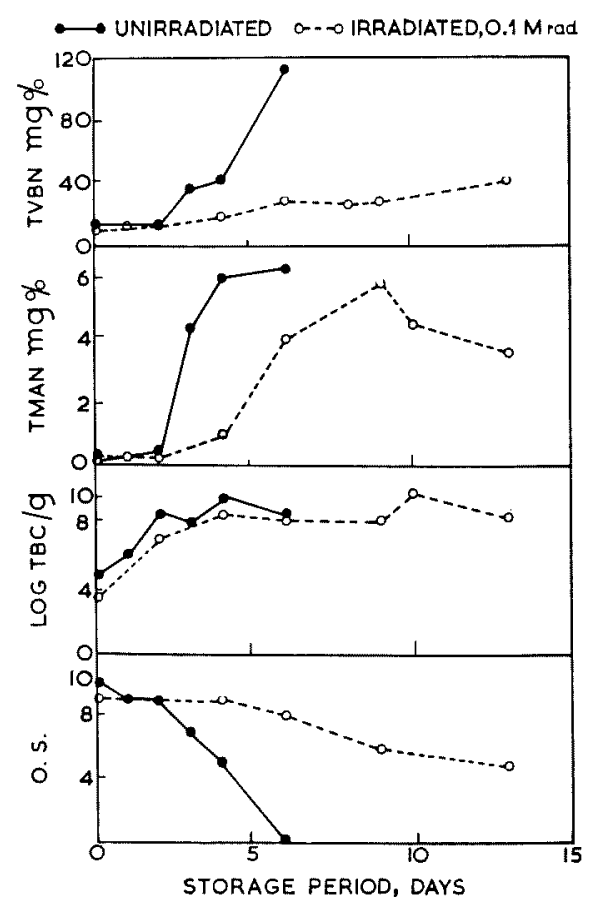

FIG. 2. Status of Freshness Indices in Bombay Duck Homogenates (storage temperature $10^{\circ} \mathrm{C}$ ).

with the rapid decline in the organoleptic acceptability of the homogenates. 


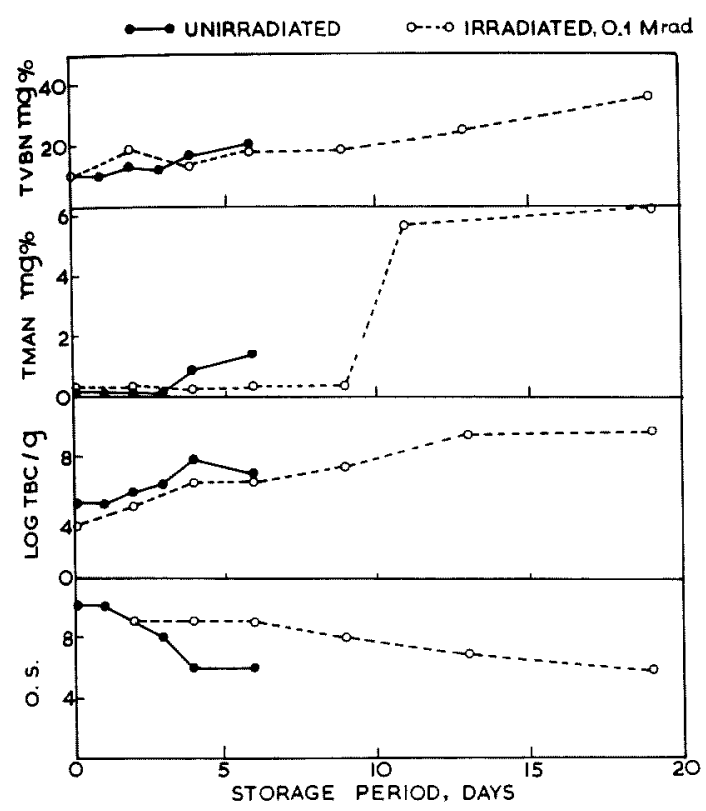

FIG. 3. Status of Freshness Indices in Unirradiated and Irradiated Bombay Duck Homogenates (storage temperature $0^{\circ} \mathrm{C}$ ).

The extension in keeping quality of samples stored at low temperature also reflects on the trend of the quality indices. Thus, samples stored at $30^{\circ} \mathrm{C}$ show high values for $\mathrm{TBC}$ $\left(10^{8} / \mathrm{g}\right)$, TMA ( $6 \mathrm{mg} \mathrm{N} \%$ ) and TVBN (100 mg $\mathrm{N} \%$ ) within $24 \mathrm{hr}$ of storage. However, homogenates stored at $10^{\circ} \mathrm{C}$ reach these levels only after $5 \sim 7$ days. Suppression in the rate of formation of TMA and TVBN is noteworthy in the samples stored at $0^{\circ} \mathrm{C}$. Low values of TMA ( $2 \mathrm{mg} \mathrm{N} \%$ ) and TVBN ( $20 \mathrm{mg}$ $\mathrm{N} \%$ ) were observed on the 7 th day of storage when the samples were rated organoleptically unacceptable.

\section{Storage properties of irradiated $(0.1 \mathrm{Mrad})$ homogenates}

An irradiation dose of $0.1 \mathrm{Mrad}$ was found to extend the storage life of the homogenates; irradiated samples were in acceptable condition for $30 \mathrm{hr}$, and for 10 and 19 days storage at $30^{\circ} \mathrm{C}, 10^{\circ}$ and $0^{\circ} \mathrm{C}$ (Figs. 1, 2 and 3) respectively.

Radiation dose of 0.1 Mrad brought about a $70 \%$ reduction in TBC. During subsequent storage, however, there was a rapid increase in TBC of samples stored both at $10^{\circ}$ and $30^{\circ} \mathrm{C}$. As seen in Fig. 3, samples stored at $0^{\circ} \mathrm{C}$ were characterised by a prolonged lag phase of about 14 days. It was interesting to note that the total bacterial counts of $10^{8} / \mathrm{g}$ or more in the irradiated samples did not indicate spoilage, since characteristic putrid odors were absent in these samples.

Formation of TVBN was suppressed initially by irradiation; TVBN contents of samples store at $30^{\circ} \mathrm{C}$ and $10^{\circ} \mathrm{C}$ for $30 \mathrm{hr}$ and 14 days respectively did not exceed $50 \mathrm{mg} \mathrm{N} \%$. Likewise, TMA formation was suppressed by irradiation, the TMA contents of samples stored for $30 \mathrm{hr}$ at $30^{\circ} \mathrm{C}$ being $2 \mathrm{mg} \mathrm{N} \%$.

Spoilage rate in terms of organoleptic score and $T B C$ for Bombay duck homogenates stored at $10^{\circ} \mathrm{C}$

As seen in Fig. 4, an inverse relationship is

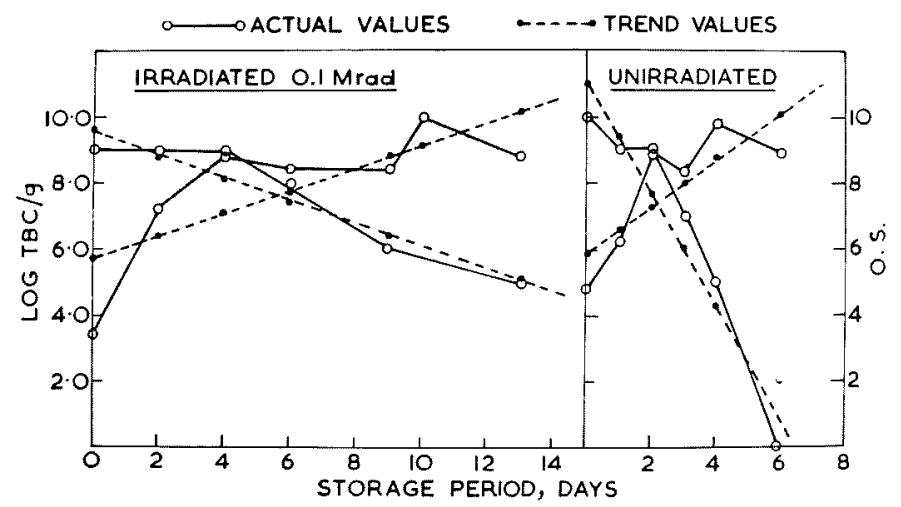

FIG. 4. Retardation in Spoilage Rates in Irradiated Bombay Duck Homogenates at $10^{\circ} \mathrm{C}-\mathrm{TBC}$ and OS. 


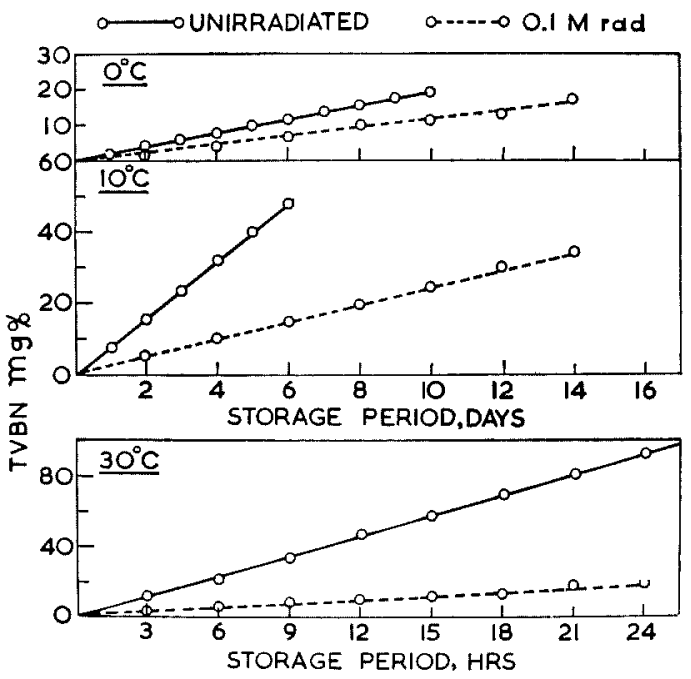

FIG. 5. Retardation in Spoilage Rates in Irradiated Bombay Duck Homogenates at $0^{\circ}, 10^{\circ}$ and $30^{\circ} \mathrm{C}$.

found to exist between TBC and OS. In the unirradiated samples, the rate of decline in acceptability (OS) is much more rapid than for irradiated samples as indicated by the steeper slope. Although irradiated samples had high TBC values, similar to those of the unirradiated samples, they were still acceptable up to 14 days storage at $10^{\circ} \mathrm{C}$ as compared with the unirradiated samples which were unacceptable after 4 days storage. These findings indicate that in the case of irradiated samples, TBC values are a poor index of spoilage. Thus a 4-fold reduction in spoilage units in terms of OS of irradiated samples indicates corresponding extension in the shelf life over the unirradiated controls.

Straight line trends for TVBN in Bombay duck homogenates during storage at $0^{\circ} \mathrm{C}, 10^{\circ}$ and $30^{\circ} \mathrm{C}$

The data shown in Fig. 5 establishes that the rate of formation of TVBN varies directly with the temperature of storage as observed from the slopes of the trends. The results also show that radiation suppressed the rate of formation of TVBN, and the temperature response to a certain extent for irradiated samples stored at $0^{\circ}, 10^{\circ}$ and $30^{\circ} \mathrm{C}$. This is evident from the increasing values of slope viz., $1.19,2.48$ and 19.68 respectively at these temperatures.

Spoilage units for chemical, microbiological and organoleptic indices

Table I indicates that spoilage rates for sensory scores of all the samples are negative, concurrent with decrease in organoleptic acceptability of the samples during storage. Spoilage rates expressed in terms of units/ day inncrease with rise in temperature. Spoilage rates calculated for $\mathrm{TBC}$ at $30^{\circ}$ and $10^{\circ} \mathrm{C}$, are respectively 13 -fold and 2 -fold as compared with samples stored at $0^{\circ} \mathrm{C}$. TMA and TVBN formation also showed similar trends in samples stored at $30^{\circ} \mathrm{C}$ and $10^{\circ} \mathrm{C}$ as compared with a storage temperature of $0^{\circ} \mathrm{C}$.

Spoilage rates in terms of organoleptic score are reduced by $3 \sim 4$ fold in irradiated samples. The spoilage units of TVBN and

TABle I. Spollage Rates of Unirradiated and IrRadiated Bombay Duck Homogenates

Spoilage units/day were calculated from the storage data on TBC, TVBN, TMA index and OS for unirradiated and irradiated $(0.1 \mathrm{Mrad})$ Bombay duck using the equation $\mathrm{U}=\mathrm{V}(1+\mathrm{C} \theta)$, where $\mathrm{U}=$ spoilage units/day at $\theta^{\circ} \mathrm{C}, \mathrm{V}=$ spoilage units/day at $0^{\circ} \mathrm{C}, \theta=\mathrm{Temp} .{ }^{\circ} \mathrm{C}$; and $\mathrm{C}=$ linear temperature response.

\begin{tabular}{|c|c|c|c|c|c|}
\hline \multirow{2}{*}{ Treatment } & \multirow{2}{*}{ Temperature } & \multicolumn{4}{|c|}{ Spoilage units/day } \\
\hline & & OS & TMA-index & TVBN & Log bact. nos. \\
\hline Unirradiated & $0^{\circ} \mathrm{C}$ & -0.86 & 0.67 & 1.93 & 0.42 \\
\hline Irradiated (0.1 Mrad) & & -0.19 & 0.55 & 1.19 & 0.31 \\
\hline Unirradiated & $10^{\circ} \mathrm{C}$ & -1.68 & 2.00 & 8.10 & 0.71 \\
\hline Irradiated (0.1 Mrad) & & -0.37 & 0.58 & 2.48 & 0.35 \\
\hline Unirradiated & $30^{\circ} \mathrm{C}$ & -9.12 & 7.20 & 93.60 & 5.42 \\
\hline Irradiated (0.1 Mrad) & & -2.4 & 0.96 & 19.68 & 6.20 \\
\hline
\end{tabular}


TMA showed $4 \sim 5$ fold decrease in irradiated samples stored at $0^{\circ}$ and $10^{\circ} \mathrm{C}$. However, such significant differences in the rates of formation of TVBN and TMA were not observed between irradiated and control samples held at $0^{\circ} \mathrm{C}$.

\section{Derivation of linear temperature response}

As seen in Table II, 'C' values for TMA, TVBN and TBC for irradiated homogenates are found to be 3.5 times lower than corresponding values for unirradiated samples. ' $\mathrm{C}$ ' values when calculated from the differences for $0^{\circ} \mathrm{C} \sim$ $30^{\circ} \mathrm{C}$, are much higher than for $0^{\circ} \mathrm{C} \sim 10^{\circ} \mathrm{C}$, thereby indicating the abrupt increase in the spoilage rate at higher temperatures of storage.

An inverse relationship between fall in organoleptic score and rise in $\mathrm{TBC}$ and chemical indices, appears to be the general pattern for unirradiated fishery products stored at melting ice temperature. It has been consistently reported ${ }^{9 \sim 11}$ that irradiation alters this relationship. Thus despite high TBC values, irradiated samples show low TVBN content and are organoleptically acceptable indicating that microorganisms which produce TVBN and putrid odors may have been suppressed. Radiation-induced alterations in microbial patterns have been reported for different varieties of sea-foods. ${ }^{12 \sim 15}$ ?

\section{Spoilage rates}

Spencer and Baines ${ }^{6)}$ reported that the rate of increase of $\log$ TBC for Hull and Aberdeen fish stored at $0^{\circ} \mathrm{C}$ ranged from $0.10 \sim 0.25$ and $0.16 \sim 0.23$ respectively. In Bombay duck, bacterial growth occurs more rapidly, the daily rate of increase being $0.42 \log$ /day. The rapid rise in TBC also reflects on the organoleptic properties of Bombay duck. Thus, the spoilage rate for Bombay duck in terms of organoleptic score is 0.86 , in contrast to spoilage units of $0.23 \sim 0.30$ observed for Hull and Aberdeen fish. These differences in the spoilage rates may be ascribed to the differences in chemical composition and types of bacteria of the fishery products. Pseudomonas which is considered to be one of the predominant spoilage groups in fishery products $^{16)}$ could not be detected in unirradiated spoiling Bombay duck. ${ }^{12,17}$ )

Spoilage rates for irradiated Bombay duck are comparatively lower than those of unirradiated samples. Retardation in spoilage rates of irradiated samples may be attributed to survival of relatively weak spoilers. ${ }^{10,18)}$ It is also significant to note that the linear temperature response is reduced for $0^{\circ}$ to $10^{\circ} \mathrm{C}$ as compared with $0^{\circ}$ to $30^{\circ} \mathrm{C}$, demonstrating that spoilage rates are essentially temperature dependent. These findings clearly indicate that the storage properties of fishery products are primarily governed by the physiological requirements of bacteria and by metabolic variations in the predominant organisms. ${ }^{19}$ ) It has been recommended ${ }^{20)}$ that temperatures in the range of $0^{\circ} \sim 3^{\circ} \mathrm{C}$ should be adopted for preventing outgrowth of pathogenic Clostridium organisms. At this temperature range, Spencer and Baines equation and a sensory score of 5 taken as a critical level of spoilage, permits calculation of storage life of radurized Bombay duck as 26 days as against 6 days for unirradiated samples similarly stored.7

TABle II. Linear Temperature Response (c) for IrRadiated Bombay Duck Homogenates

Linear temperature response (c) was calculated for temperature ranges of $0^{\circ} \mathrm{C} \sim 10^{\circ} \mathrm{C}$ and $0^{\circ} \mathrm{C} \sim 30^{\circ} \mathrm{C}$ for TBC, OS, TMA-index and TVBN using the equation given in Table I.

\begin{tabular}{lccccc}
\multicolumn{1}{c}{ Treatment } & $\begin{array}{c}\text { Temperature } \\
\text { range }\end{array}$ & $\begin{array}{c}\text { Organoleptic } \\
\text { scores }\end{array}$ & $\begin{array}{c}\text { Bact. log } \\
\text { nos. }\end{array}$ & TMA-index & TVBNmg \% \\
\hline Unirradiated & $0^{\circ} \mathrm{C} \sim 10^{\circ} \mathrm{C}$ & 0.30 & 0.05 & 0.20 & 0.32 \\
Irradiated $(0.1$ Mard $)$ & & 0.29 & 0.01 & 0.05 & 0.11 \\
Unirradiated & $0^{\circ} \mathrm{C} \sim 30^{\circ} \mathrm{C}$ & 0.38 & 0.40 & 0.32 & 1.6 \\
Irradiated $(0.1 \mathrm{Mrad})$ & & 0.36 & 0.63 & 0.03 & 0.55 \\
\hline
\end{tabular}


Hence, any temperature fluctuation resulting from abuse of radurized products during commercial transport, would give higher spoilage rates and thus would indicate that these samples may not qualify for consumer distribution.

\section{REFERENCES}

1) N. F. Lewis, M. D. Alur, A. R. Nadkarni, S. G. Gaonkar and U. S. Kumta, in "Radiation Preservation of Food," IAEA, Vienna, p. 201 (1973).

2) U. S. Kumta and A. Sreenivasan, in "Food Irradiation," IAEA, Vienna (1966).

3) U. S. Kumta, K. A. Savagaon, S. V. Ghadi, S. N. Doke, M. S. Gore, V. Venugopal, V. N. Madhavan and A. Sreenivasan, in "Radiation Preservation of Food," IAEA, Vienna, p. 403 (1973).

4) M. W. Eklund and F. T. Poysky, in "Panel on the Irradiation Preservation of Foods of Marine Origin," IAEA, Vienna (1969).

5) R. Bhadra, D. R. Chaudhuri and A. N. Bose, in "Radiation Preservation of Food," IAEA, Vienna, p. 221 (1973).

6) R. Spencer and C. R. Baines, Food Technol., 18, 769 (1964).

7) U. S. Kumta, M. D. Alur, S. S. Mavinkurve and
N. F. Lewis, J. Fd. Sci., 36, 831 (1971).

8) D. Miyauchi, M. Eklund, J. Spinelli and N. Stoll, Food Technol., 18, 928 (1964).

9) P. L. Sawant, S. S. Mavinkurve, S. Saroja, K. A. Savagaon and U. S. Kumta, ibid., 21, 444 (1967).

10) U. S. Kumta, S. S. Mavinkurve, M. S. Gore, S. V. Gangal, P. L. Sawant and A. Sreenivasan, J. Fd. Sci., 35, 360 (1970).

11) J. Spinelli, M. Eklund and D. Miyauchi, Food Technol, 18, 143 (1964).

12) S. S. Mavinkurve, S. V. Gangal, P.L. Sawant and U. S. Kumta, J. Fd. Sci., 32, 711 (1967).

13) D. P. Maclean and C. Welander, Food Technol., 14, 251 (1960).

14) E. B. Masurovsky, J. S. Voss and S. A. Goldblith, Appl. Microbiol., 11, 229 (1963).

15) D. A. Corlett, J. S. Lee and R. O. Sinnhuber, Appl. Microbiol., 13, 818 (1965).

16) B. G. Shaw and J. M. Shewan, J. Appl. Bacteriol., 31, 89 (1968).

17) U.S. Kumta and S. S. Mavinkurve, J. Fd. Sci, 36, 63 (1971).

18) N. F. Lewis, M. D. Alur and U. S. Kumta, Ind. J. Exp. Biol., 9, 45 (1971).

19) M. D. Alur, N. F. Lewis and U. S. Kumta, ibid., 9, 48 (1971).

20) IAEA, in "Microbiological Problems in Food Preservation by Irradiation" (1967). 